\title{
Analisis Isu Pemilihan Presiden 2019 Di Media Sosial Whatsapp Mahasiswa Universitas Negeri Padang
}

\author{
Mega Aprillia, Al Rafni \\ Program Studi Pendidikan Pancasila dan Kewarganegaraan \\ Universitas Negeri Padang \\ E-mail: aprilliamega97@gmail.com
}

\section{ABSTRAK}

Pemilihan Presiden periode 2019-2024 menimbulkan berbagai macam isu politik di kalangan masyarakat terutama mahasiswa terhadap masing - masing kandidat dari pasangan calon presiden tersebut. Untuk itu, peneliti tertarik untuk menganalisis isi grup WhatsApp Unit Kegiatan Wadah Pengkajian dan Pengembangan Sosial Politik (UK-WP2SOSPOL) yaitu grup "KELUARGA BESAR UKWP2SOSPOL" dan "UNP Kito Basamo" di Universitas Negeri Padang. Dalam penelitian ini, peneliti menggunakan metode analisis isi kualitatif. Hasil yang di dapatkan yaitu isu politik yang banyak tersebar di kalangan mahasiswa tersebut yaitu diantaranya mengenai Figur, Keagamaan, Pendidikan, Pemerintahan, Perekonomian, Pertahanan dan Keamanan, Pemilihan Umum, Pembangunan, Media Massa, Hukum dan Politik. Berdasarkan hasil analisis tersebut, isu politik yang paling banyak dibicarakan dikalangan mahasiswa adalah kategori pemerintahan, yaitu terkait dengan tidak adanya perlindungan serta ketidakadilan yang diberikan oleh pemerintah terhadap rakyatnya. Hal tersebut dapat dilihat dari dibiarkannya ratusan anggota KPPS yang meninggal dunia ketika menjalankan tugasnya sebagai anggota KPPS, serta banyaknya kekerasan yang di alami oleh rakyat ketika terjadinya demo dan pemerintah tidak memberikan perlindungan terhadap rakyat tersebut. Isu politik selanjutnya yaitu terjadinya pembungkaman pendapat di masa pemerintahan Jokowi periode sebelumnya.

Kata Kunci: isu politik, mahasiswa, UK-WP2SOSPOL, Universitas Negeri Padang

\section{ABSTRACT}

The Presidential Election period 2019-2024 raises a variety of political issues in the community, especially students of each candidate from the presidential candidate pair. The researchers are interested in analyzing the contents of the WhatsApp Group for the Study on Social and Political Development and Development (UK-WP2SOSPOL) groups, namely the "BSAR FAMIL Y UKWP2SOSPOL" and "UNP Kito Basamo" groups at Universitas Negeri Padang. In this study, researchers used qualitative content analysis methods. And the results obtained, the political issues that are widely spread among these students include those concerning Figure, Religion, Education, Government, Economy, Defense and Security, Elections, Development, Mass Media, Law and Politics. And based on the results of the analysis, the most discussed political issue among students is the government category, which is related to the absence of protection and injustice provided by the government to its people. 
This can be seen from the letting of hundreds of KPPS members who died while carrying out their duties as KPPS members, as well as the amount of violence experienced by the people when the demonstration occurred and the government did not provide protection for these people. The next political issue is the silencing of opinions during the Jokowi's administration in the previous period.

Keywords : political issues, UK-WP2SOSPOL, Universitas Negeri Padang

This work is licensed under the Creative Commons Attribution-ShareAlike 4.0 International License. (C)2019 by author.

\section{PENDAHULUAN}

Pemilihan Calon Presiden dan Wakil Presiden periode 2019-2024 memiliki suatu keunikan tersendiri, karena masing-masing calonnya memiliki ciri khas yang berbeda dalam mengambil simpati masyarakat. Jokowi memilih calon wakil presidennya melalui kesepakatan yang diambil bersama sembilan partai politik pendukungnya yaitu menyarankan agar berpasangan dengan ulama. Hal ini selaras dengan kutipan pada Kompas.com, (2018) yang memaparkan bahwa Jokowi memilih seorang tokoh ulama yaitu Prof. KH. Ma'ruf Amin yang akan dijadikan sebagai wakilnya dengan alasan bahwa Ma'ruf Amin adalah tokoh agama yang bijaksana dan bisa menjadi pasangan yang saling melengkapi satu sama lainnya. Disisi lain, Prabowo memilih untuk tidak menjalankan rekomendasi ijtima' ulama disebabkan karena Prabowo tidak ingin membenturkan antar tokoh ulama. Sehingga Prabowo memilih Sandiaga S Uno sebagai wakilnya diajang pemilihan presiden 2019 (JawaPos.com, 2018).

Fenomena yang terjadi di Pemilihan Presiden periode 2019-2024 ini akan menimbulkan berbagai macam isu politik di kalangan masyarakat terutama mahasiswa terhadap masing-masing kandidat dari pasangan calon presiden dan calon wakil presiden. Berbagai macam isu politik muncul bisa dari iklan politik, pandangan masyarakat terhadap politik maupun dari berita media sosial yang berkaitan dengan politik lainnya.

Seiring perkembangan Ilmu Pengetahuan dan Teknologi di era modern ini, media sosial berperan penting dalam pemilihan presiden 2019. Menurut Damayanti dan Purworini dalam Saleh \& Pitriani (2018), media sosial unggul dalam memberikan kecepatan informasi sehingga membuat penggunanya semakin dinamis dan apatis termasuk dalam hal pemilihan presiden 2019. Media sosial saat ini sangat digemari oleh berbagai kalangan dan dianggap cukup efektif oleh masyarakat Indonesia. WhatsApp merupakan salah satu contoh media sosial yang paling dominan digunakan pada saat ini. WhatsApp adalah aplikasi pesan berbasis pesan untuk smartphone dengan basic mirip BlackBerry Messenger.

WhatsApp messenger merupakan aplikasi pesan lintas platform yang memungkinkan kita bertukar pesan tanpa biaya sms, karena WhatsApp messenger merupakan paket data internet yang 
sama untuk email, browsing web dan lain-lain (Suryani:2017). Seiring banyaknya media sosial WhatsApp yang digemari oleh berbagai kalangan, tidak menutup kemungkinan bahwa masih ditemukan kurangnya pengetahuan mahasiswa tentang penggunaan media sosial WhatsApp ini sebagai salah satu bentuk komunikasi politik.

Isu politik adalah suatu keadaan dimana timbulnya ketidaksesuaian antara suatu kepemerintahan dengan harapan public. Apabila diabaikan akan berdampak terhadap pemerintahan itu sendiri. Isu-isu politik yang berkembang pada Pemilu 2019 ini sebenarnya tidak jauh berbeda dengan isu-isu politik yang terjadi pada masa Pemilu 2014. Semuanya masih mengedepankan isu yang menyangkut politik identitas.

Terkait isu politik, menurut penelitian yang telah dilakukan oleh Riyanto \& Hastuti (2017) pada mahasiswa Surakarta, mereka menyimpulkan bahwa mahasiswa perlu meningkatkan pengetahuannya lagi tentang proses pemberitaan, wawasan umum dan daya kritisnya dalam menangkal berita-berita hoax yang banyak beredar di media sosial khususnya WhatsApp. Selaras dengan hal ini, di kalangan mahasiswa masih ditemukan mahasiswa yang memiliki persepsi tentang isu kandidat pemilihan presiden 2019 yang saling memojokkan dan membanggakan dirinya masing-masing untuk menarik simpati masyarakat pada umumnya. Penelitian sebelumnya dari Prathiwi (2014) yaitu mengenai persepsi mahasiswa tentang calon Presiden RI 2014-2018" menyatakan bahwa banyak partai yang terpecah belah dalam memilih presiden. Misalnya Jusuf Kalla sendiri merupakan anggota dari partai Golkar sedangkan Partai Golkar mendukung Prabowo.

Selain itu Mahfud MD yang awalnya akan dijadikan sebagai calon presiden dari PKB dan anggota dari PKB menjadi ketua pemenangan dari Prabowo. Penelitian lain mengenai persepsi terhadap Pemilihan Presiden juga dilakukan oleh Triastari (2011) yaitu mengenai persepsi iklan politik pada pemilih pemula". Dalam hal ini menyatakan bahwa pilihan politik masyarakat tidak selalu ditentukan oleh banyaknya informasi yang mereka miliki tentang kandidat, tetapi juga dipengaruhi oleh kapasitas masyarakat untuk mengolah informasi itu. Penelitian lain juga dilakukan oleh Rahayu \& Wijaya (2017) mengenai persepsi mahasiswa atas terpaan isu politik terhadap citra calon Presiden dan Wakil Presiden pada Pemilu 2014. Penelitian ini menyatakan bahwa pemilihan presiden tahun 2014 menyajikan pertarungan politik dengan tensi tinggi, banyak isu negatif yang menerpa masing-masing kandidat. Kemudian penelitian ini juga diperkuat oleh Suryanef (2011) yang menyatakan bahwa mahasiswa FIS UNP lebih banyak berpendapat bahwa dalam dunia politik, kelicikan memang hal yang lumrah terjadi di dalam pertarungan politik.

Sejauh ini belum ada penelitian mengenai isu politik dalam dinamika Pemilihan Presiden. Pada umumnya peneliti lain hanya baru mengkaji mengenai Pemilihan Presiden 2014 dan belum mengkaji mengenai Pemilihan Presiden 2019 yang mempunyai keunikan tersendiri dengan menggunakan performa pertarungan politik yang berbeda dari 
Pemilihan Presiden pada periode sebelumnya. Masalah ini akan menarik untuk dijadikan penelitian karena telah banyaknya isu-isu politik yang beredar di kalangan masyarakat khususnya pada mahasiswa pada masa Pemilihan Presiden 2019. Hal ini akan menimbulkan berbagai macam persepsi bagi setiap mahasiswa terkait dengan para masing-masing pasangan calon Presiden 2019. Selaras dengan hal itu, maka peneliti disini tertarik untuk menganalisis isu-isu politik dalam Pemilihan Presiden 2019 di media sosial WhatsApp, karena WhatsApp merupakan salah satu media sosial yang banyak digunakan oleh kalangan mahasiswa pada umumnya.

\section{METODE PENELITIAN}

Pendekatan yang digunakan dalam penelitian ini adalah pendekatan kualitatif dengan teknik penelitiannya adalah analisis isi (content analysis) dengan hasil akhir berupa kata-kata tertulis. Penelitian ini dilakukan pada mahasiswa UNP UKWP2SOSPOL. Hal ini dikarenakan UKWP2SOSPOL adalah salah satu wadah organisasi mahasiswa UNP yang membahas mengenai dunia perpolitikan di Indonesia. Terkait mengenai data-data yang dibutuhkan, penulis menelusuri grup WhatsApp "KELUARGA

BESAR UKWP2SOSPOL" dan "UNP Kito Basamo" untuk dijadikan sebagai data dokumentasi. Grup WhatsApp "KELUARGA BESAR UKWP2SOSPOL" ini adalah sebuah grup yang digunakan oleh UKWP2SOSPOL untuk bersosialisasi antar sesama anggotanya dan juga untuk membahas terkait perpolitikan yang terjadi di Indonesia. Sedangkan grup WhatsApp "UNP Kito Basamo" adalah sebuah grup yang dibuat oleh mahasiswa UNP itu sendiri. Isi pembicaraannya juga banyak mengenai perpolitikan yang terjadi di Indonesia.

Lebih lanjut terkait mengenai penelitian penulis terhadap isu politik dalam Pemilihan Presiden 2019, maka penulis menelusuri isi pembicaraan terkait mengenai isu politik dalam Pemilihan Presiden 2019 pada kedua grup ini. Selanjutnya, setelah penulis menelusuri isi grup, penulis mengambil tangkapan layar (menscreenshot) pembicaraan terkait isu-isu politik tersebut. Pada akhirnya penulis mendapatkan 153 hasil tanggapan layar dengan jumlah pembicaraannya sebanyak 46 orang. Dari hasil yang didapatkan ini, peneliti sertai dengan mewawancarai 3 informan dari grup tersebut untuk kejelasan topik yang dibahas. Terkait mengenai fokus penelitian penulis berkisar pada Pemilihan Presiden 2019, maka peneliti membatasi isi pembicaraan grup tersebut yaitu dari bulan Desember 2018 sampai dengan Mei 2019.

Data yang telah penulis dapatkan terkait mengenai pembicaraan isu politik dalam Pemilihan Presiden 2019, semuanya penulis screenshoot dan diolah ke dalam lembar coding atau penulis istilahkan dengan blanko koding. Kemudian penulis mengklasifikasikan isu politik tersebut ke dalam sebelas kategori topik tentang Pemilihan Presiden 2019. Informan dalam penelitian ini diantaranya Ketua Umum UKWP2SOSPOL UNP, pembuat grup UNP Kito Basamo, dan Ketua/anggota dari Riset Politik UK-WP2SOSPOL UNP. 


\section{HASIL DAN PEMBAHASAN}

Berdasarkan langkah-langkah yang telah peneliti lakukan terhadap data tangkapan layar dari grup "KELUARGA BESAR UKWP2SOSPOL dan "UNP Kito Basamo" yang membahas terkait Isu Politik dalam Pemilihan Presiden 2019 di Media Sosial WhatsApp, maka peneliti mendapatkan hasilnya sebagai berikut:

Tabel 1. Jumlah Pembahasan Pemilihan Presiden 2019 di Grup WhatsApp Berdasarkan 11 Kategori

\begin{tabular}{|c|l|c|c|c|}
\hline No & \multicolumn{1}{|c|}{ Kategori } & $\begin{array}{c}\text { Jumlah Anggota } \\
\text { yang Membahas } \\
\text { tentang Jokowi- } \\
\text { Ma'ruf }\end{array}$ & $\begin{array}{c}\text { Jumlah Angggota } \\
\text { yang Membahas } \\
\text { tentang } \\
\text { Prabowo-Sandi }\end{array}$ & Total \\
\hline 1. & Figur & 7 Orang & 9 Orang & 16 Orang \\
\hline 2. & Keagamaan & 2 Orang & 2 Orang & 4 Orang \\
\hline 3. & Pendidikan & 4 Orang & - & 4 Orang \\
\hline 4. & Pemerintahan & 41 Orang & - & 41 Orang \\
\hline 5. & Perekonomian & 14 Orang & - & 14 Orang \\
\hline 6. & Pertahanan dan Keamanan & 11 Orang & - & 11 Orang \\
\hline 7. & Pemilihan Umum & 4 Orang & - & 4 Orang \\
\hline 8. & Pembangunan & 9 Orang & 2 Orang & 11 Orang \\
\hline 9. & Media Massa & 4 Orang & - & 4 Orang \\
\hline 10. & Hukum & 8 Orang & - & 8 Orang \\
\hline 11. & Politik & 3 Orang & 9 Orang & 12 Orang \\
\hline
\end{tabular}

Berdasarkan tabel di atas, setalah penulis mengklasifikasikan pembicaraan terkait mengenai isu politik dalam Pemilihan Presiden 2019 pada grup WhatsApp "KELUARGA BSAR UKWP2SOSPOL dan " UNP Kito Basamo" ke dalam sebelas kategori, maka selanjutnya penulis memasukkan hasil pembahasan tersebut ke dalam tabel persentase seperti di bawah ini, hal ini berguna untuk mengetahui kategori manakah yang lebih dominan yang dibicarakan oleh mahasiswa terkait mengenai isu politik dalam Pemilihan Presiden 2019 di media sosial grup WhatsAppnya.

Cara mendapatkan hasil dari tebel persentase tersebut ialah dengan deskriptif dalam bentuk persentese dengan menggunakan rumus sebagai berikut:

$$
\mathrm{P}=\mathrm{F} / \mathrm{n} \times 100 \%
$$

Keterangan: $\mathrm{P}=$ Hasil akhir dalam persentase

$\mathrm{F}=$ Frekuensi data (Jumlah pembicara/informan yang membahas isu politik yang terkait diantara kesebelas kategori di atas)

$\mathrm{n}=$ Jumlah responden

Berdasarkan rumus di atas, maka didapat persentase sebagai berikut:

Tabel 2. Hasil Persentase dari Pembahasan Pemilihan Presiden 2019 di Grup WhatsApp Berdasarkan 11 Kategori

\begin{tabular}{|l|l|c|c|c|}
\hline No & \multicolumn{1}{|c|}{ Kategori } & $\begin{array}{c}\text { Hasil Persentase } \\
\text { yang Membahas } \\
\text { tentang Jokowi- } \\
\text { Ma'ruf }\end{array}$ & $\begin{array}{c}\text { Hasil Persentase } \\
\text { yang Membahas } \\
\text { tentang } \\
\text { Prabowo-Sandi }\end{array}$ & $\begin{array}{c}\text { Total } \\
\text { Persentase }\end{array}$ \\
\hline 1. & Figur & $15,21 \%$ & $19,56 \%$ & $34,77 \%$ \\
\hline 2. & Keagamaan & $4,34 \%$ & $4,34 \%$ & $8,68 \%$ \\
\hline 3. & Pendidikan & $8,69 \%$ & $0 \%$ & $8,69 \%$ \\
\hline 4. & Pemerintahan & $89,13 \%$ & $0 \%$ & $89,13 \%$ \\
\hline 5. & Perekonomian & $30,43 \%$ & $0 \%$ & $30,43 \%$ \\
\hline 6. & Pertahanan dan Keamanan & $23,91 \%$ & $0 \%$ & $23,91 \%$ \\
\hline 7. & Pemilihan Umum & $8,69 \%$ & $0 \%$ & $8,69 \%$ \\
\hline 8. & Pembangunan & $19,56 \%$ & $4,34 \%$ & $23,90 \%$ \\
\hline 9. & Media Massa & $8,69 \%$ & $0 \%$ & $8,69 \%$ \\
\hline 10. & Hukum & $17,39 \%$ & $0 \%$ & $17,39 \%$ \\
\hline 11. & Politik & $6,52 \%$ & $19,56 \%$ & $26,08 \%$ \\
\hline
\end{tabular}

Lebih lanjut, berdasarkan hasil persentase dari tabel di atas, maka hasil penelitian ini dapat dijabarkan sebagai berikut:

\section{Figur}

Figur berkaitan dengan sosok atau kepribadian yang dimiliki oleh masing-masing pasangan JokowiMa'ruf dan Prabowo-Sandi. Dalam kategori ini pasangan Presiden JokowiMa'ruf menuai isu yang berkaitan dengan kesederhanaan dan kedekatannya dengan masyarakat, pencitraan, ketampanan, berbicara 
yang masih gagap, sangat kurus, kurang tegas, dan mudah terpengaruh oleh pihak lain. Dari semua ini, isu-isu yang banyak beredar yaitu mengenai fisik dan cara berbicaranya bapak Jokowi. Informan berpendapat bahwa Jokowi sangat kurus dan cara berbicaranya dianggap masih gagap.

Sedangkan pasangan Presiden Prabowo-Sandi menuai isu mengenai kehausannya dalam jabatan, jenderal yang hebat, di pecat jadi tentara, gagal menjadi seorang suami, kepribadian yang buruk, dan tidak mengeluarkan zakat. Dari isu-isu ini, isu yang banyak beredar yaitu mengenai pribadi Prabowo yang buruk berkaitan dengan tragedi Mei 1998. Informan berpendapat bahwa dengan kepribadian yang buruk maka tidak bisa menjamin bagaimana nasib negara kedepannya. Informan juga berpendapat bahwa pelanggar HAM terkait tragedi Mei 1998 tidak pantas menjadi pemimpin.

\section{Keagamaan}

H-hal yang berhubungan dengan keagamaan dari masing-masing pasangan presiden contohnya adalah cara masing-masing pasangan presiden dalam melafalkan kata-kata yang berhubungan dengan agama seperti pengucapan kata salam, basmalah, dan lain sebagainya.

Terkait kategori ini, pasangan Presiden Jokowi-Ma'ruf menuai isu mengenai pembacaan Al-fatihah dan basmalahnya bapak Jokowi yang tidak lurus, suara toa azan yang dikecilkan, serta banyaknya antek-antek kaum kafir di masa pemerintahan Jokowi dulu. Terkait dengan isu-isu yang beredar ini, semuanya menjadi isu yang banyak dibicarakan oleh kalangan informan pada umumnya.
Informan berpendapat bahwa ucapan Al-fatihah dan basmalah yang dilontarkan oleh Jokowi bacaannya tidak lurus atau dalam kata lain tidak fasih seperti bacaan dari kebanyakan umat islam lainnya. Selain itu, Jokowi juga mendapat kritikan terkait dengan masalah suara toa azan. Informan mengatakan bahwa dalam masa pemerintahan Jokowi selama satu periodenya lalu, antek-anteknya banyak dari kalangan non-muslim. Mengenai suara toa azan, baru kali ini suara toa azan tersebut dipermasalahkan. Padahal sejak zaman dahulu tidak ada masalah terkait dengan suara toa azan yang harus dikecilkan.

Selanjutnya mengenai pasangan Presiden Prabowo-Sandi juga menuai banyak kritikan tentang bacaan salam, Al-fatihah dan basmalahnya. Informan berpendapat bahwa pelafalan bacaan Al-fatihah dan basmalahnya Prabowo masih diragukan kelurusannya. Sebab, bacaan salam Prabowo yang tidak lurus atau dalam arti lain kurang sempurna dalam pelafalannya.

\section{Pendidikan}

Pendidikan berkaitan dengan hal-hal yang berhubungan dengan perkembangan pendidikan, partisipasi dari masing-masing pasangan calon presiden di dunia pendidikan. Isu terkait dengan kategori pendidikan hanya ada pada pasangan presiden Jokowi -Ma'ruf yaitu mengenai keinginan Menteri dalam Negeri terkait perihal pengimporan guru dari luar negeri, pengusulan game online ke dalam sistem kurikulum, dan masalah pemilihan Rektor. Mengenai isu-isu ini, isu yang banyak menjadi pembicaraan yaitu mengenai Mendagri yang mengatakan bahwa 
pemilihan rektor tak lagi dilakukan oleh Dikti namun dipilih oleh Presiden. Mengenai hal ini, banyak informan yang tidak setuju mengenai keputusan dari Mendagri tersebut.

\section{Pemerintahan}

Pemerintahan berkaitan dengan tindakan pemerintah dalam menyelesaikan permasalahan yang terjadi pada masa pemerintahannya tersebut. Terkait dengan isu pemerintahan, kategori ini hanya ada pada pasangan presiden JokowiMa'ruf. Hal ini disebabkan karena Jokowi pernah memimpin Indonesia selama satu periode lalu. Isu yang dibicarakan dalam kategori diantaranya yaitu mengenai pengiriman 3 juta warga China ke Indonesia, anti demokrasi dan keotoriteran Jokowi dalam memimpin, kehancuran negara, bebasnya tenaga asing masuk ke Indonesia, banyaknya TKI yang di PHK, tenaga honorer yang sudah lebih dari 20 tahun yang belum juga diangkat, konsep negara khilafah, banyaknya rakyat yang terzolimi, melakukan PHK ilegal, mensejahterakan negara, menebar janji-janji palsu, tidak membawa dampak kesejahteraan, membuat vlog dengan cucu, melarikan diri disaat terjadinya protes, dan terjadinya pembungkaman pendapat.

Dari semua isu-isu ini, isu yang menuai banyak pembicaraan dari informan yaitu mengenai banyaknya rakyat yang terzolimi di masa pemerintahan Jokowi selama satu periode pemerintahannya. Informan banyak mengatakan bahwa dalam keadaan rakyat sedang tertindas sementara pemerintah hanya diam tanpa mengambil tindakan apapun. Kedua, mengenai janji-janji palsu yang
Volume 1 No. 42018

diberikan Jokowi. Informan mengatakan bahwa Jokowi hanya bisa menebar janji tapi tidak ada yang terbukti dan terlealisasi. Ketiga, mengenai suara rakyat yang dibungkam pada masa pemerintahannya selama satu periode lalu. Informan berpendapat bahwa yang ada dipemikiran rakyat saat ini adalah takut untuk mengkritik dan mengeluarkan pendapat terkait dengan urusan kepemerintahan, karena rakyat diancam akan berhadapan dengan aparat kepolisian apabila rakyat ketahuan dalam menebar berita-berita hoax.

\section{Perekonomian}

Perekonomian berkaitan dengan keadaan ekonomi masyarakat Indonesia pada masa pemerintahan pasangan presiden tersebut. Seperti kurs dollar meningkat, tingkat hutang meningkat, dan lain lain. Terkait perekonomian, kategori ini hanya ada pada pasangan presiden JokowiMa'ruf. Hal ini juga disebabkan karena Jokowi pernah memimpin Indonesia selama satu periode lalu. Isu-isu yang beredar dalam kategori perekonomian ini yaitu mengenai guru honor yang belum digaji, BPJS belum dibayar, hutang menumpuk, tol banjir, tarif listrik naik, BBM naik secara diamdiam, pembayaran BPJS naik

Selanjutnya juga dibahas mengenai dana haji dipergunakan untuk jalan tol, asing diperkaya, kurs dollar makin naik, harga sembako yang merangkak naik secara diamdiam, program realokasi anggaran subsidi BBM, mampu memperbaiki perekonomian bangsa, mengurangi angka kemiskinan, serta menghasilkan PDB diatas US\$1 Triliun. Mengenai isu-isu yang tersebar ini, isu yang 
banyak menuai pembicaraan dari kalangan informan yaitu mengenai ketidaksejahteraan rakyat serta kehancuran yang terjadi di bidang perekonomian tersebut. Informan mengatakan bahwa selama pemerintahan Jokowi satu periode lalu, dalam bidang perekonomian, beliau tidak membawa perubahanan apapun, kurs dollar dan tarif listrik semakin naik, serta harga sembako dan minyak juga naik secara diam-diam tanpa ada pemberitahuan apapun.

\section{Pertahanan dan Keamanan}

Pertahanan dan keamanan berkaitan dengan aparat-aparat negara dalam menjalankan tugasnya untuk mengayomi dan melindungi rakyat Indonesia serta menjamin keamanan negara Indonesia. Terkait dengan kategori pertahanan dan keamanan ini, isu yang tersebar hanya untuk pasangan Presiden Jokowi-Ma'ruf. Isuisu yang tersebar di antaranya mengenai aparat-aparat negara yang kesadisannya seperti tentara Israel, remaja yang dianiaya oleh pihak polisi karena membuat rusuh saat demo, dan mengenai aparat-aparat negara yang berbuat kecurangan dan terus mencari kesalahan rakyatnya. Isu yang banyak dibicarakan oleh para informan yaitu mengenai isu kecurangan oleh aparataparat pemerintahan. Informan mengatakan bahwa aparat-aparat negara pada masa pemerintahan Jokowi periode pertama tega menghakimi rakyatnya secara bersama-sama hanya karena masyarakat tersebut membuat kerusahan pada saat aksi demo berlangsung. Lebih lanjut, informan juga mengatakan bahwa aparat-aparat pemerintah tidak menjalankan tugas sebagaimana mestinya. Mereka selalu mencari-cari kesalahan yang diperbuat oleh rakyat.

\section{Pemilihan Umum}

Pemilu berkaitan dengan hal-hal yang berhubungan dengan keberlangsungan pemilihan umum seperti KPU, BAWASLU, Panitia TPS, dan lain sebagainya. Pada kategori ini hanya mengenai pasangan Presiden Jokowi-Ma'ruf, hal ini disebabkan karena pemilu ini terjadi di masa pemerintahan Jokowi. Isu-isu yang dibahas dalam pemilu yaitu terkait dengan pemungutan suara yang memakan korban hampir seribu orang dan isu terjadinya kecurangan pada saat berlangsungnya pemilu. Isu-isu tersebut yang banyak dibicarakan oleh para informan yaitu terkait dengan kecurangan yang dilakukan oleh KPU dan Bawaslu. Informan mengatakan bahwa banyak bukti-bukti kecurangan yang telah tersebar, seperti videovideo kecurangan pada saat pemilihan umum berlangsung dan diumumkannya di malam hari pemenang pemilihan presiden 2019 oleh pihak KPU.

\section{Pembangunan}

Pembangunan berkaitan dengan infrastruktur yang dibangun untuk kesejahteraan masyarakat Indonesia seperti pembangunan jalan tol, rumah siap kerja untuk mengatasi pengangguran, dan lain lain. Pada kategori pembangunan ini, diantara isu-isu yang beredar yaitu mengenai pembangunan jalan tol, pembayaran jika melewati jalan tol, tanah rakyat Indonesia yang banyak belum dibayar, pembangunan atas kepemilikan China, dan pembangunan atas nama hutang. Isu yang banyak beredar di kalangan mahasiswa yaitu mengenai pembangunan yang telah banyak di 
bangun oleh Jokowi di masa pemerintahannya satu periode lalu, yaitu mengenai pambangunan jalan tol. Selanjutnya terhadap pasangan Presiden Prabowo-Sandi, isu-isu yang beredar yaitu mengenai Sandiaga Uno yang meresmikan rumah siap kerja untuk mengatasi penggangguran.

\section{Media Massa}

Media massa berkaitan dengan pemberitaan-pemberitaan di media tentang pemerintahan atau perpolitikan yang terjadi di Indonesia. Terkait kategori media massa ini, isu yang tersebar hanya mengenai pasangan Presiden Jokowi-Ma'ruf. Hal ini disebabkan karena permasalahan terkait media massa ini terjadi di masa pemerintahan Jokowi. Isu yang tersebar dalam kategori ini adalah bungkamnya media massa terkait dengan permasalahan-permasalahan yang terjadi di dalam negeri, terutama mengenai masalah politik. Informan mengatakan bahwa semua media bungkam tentang keadaan buruk yang dialami Indonesia. Media hanya sibuk meliput urusan politik terkait dengan Jokowi. Informan juga mengatakan bahwa pada masa sekarang ini sulit untuk mencari berita yang benar karena semua media hanya pro terhadap Jokowi.

\section{Hukum}

Hukum berkaitan dengan keadaan hukum yang terjadi di Indonesia. Seperti ketidakadilan dalam penegakan hukum dan lain sebagainya. Terkait kategori ini, isu yang tersebar hanya mengenai pasangan Presiden Jokowi-Ma'ruf. Isu yang dibicarakan terkait kategori ini adalah mengenai ketidakadilan penegakan hukum. Informan mengatakan bahwa ketika ada dokter yang mengusut atau menyarankan untuk memvisum ratusan anggota KPPS yang meninggal, tetapi malah dokter tersebut yang disidik. Informan juga mengatakan bahwa para penegak hukum memang pintar namun tidak mempunyai akhlak karena dengan mudahnya mereka membenarkan hal yang salah.

\section{Politik}

Politik berkaitan dengan cara masing-masing pasangan calon dalam mengambil simpati masyarakat. Seperti Jokowi menjanjikan memberikan kartu-kartu (KIP, KIS, dan lain-lain) kepada masyaraka miskin. Disisi lain Prabowo menggandeng tokoh-tokoh ulama sebagai pendukungnya.

Terkait kategori ini, isu yang tersebar mengenai pasangan Presiden Jokowi-Ma'ruf diantaranya yaitu tentang janji Jokowi yang menawarkan kartu sembako murah, KIP kuliah, dan kartu pra-kerja. Informan mengatakan bahwa mereka dapat menerima janjijanji yang diberikan oleh Jokowi dan berharap Jokowi menepati janjinya tersebut. Informan lain juga mengatakan bahwa senang jika mendapatkan kartu karena hanya dengan tidur-tiduran di rumah bisa mendapatkan uang sejumlah $\mathrm{Rp}$ 5.500.000.

Selanjutnya mengenai isu yang tersebar pada pasangan Presiden Prabowo-Sandi diantaranya, pertama pasangan calon presiden ini mempermasalahkan TKA karena merugikan rakyat Indonoesia. Kedua, Sandiaga Uno mengucapkan bela sungkawa untuk umat muslim di Selandia Baru serta juga mengucapkan bela sungkawa terhadap bencana yang 
terjadi di Papua. Hal ini berbeda dengan Ma'ruf Amin selaku ulama Indonesia yang tidak mengucapkan bela sungkawa. Ketiga, PrabowoSandi memberikan kepastian hukum dan jaminan berserikat kepada ojek online. Terakhir, mengenai banyaknya ulama yang menjadi tim sukses dari pasangan Presiden Prabowo-Sandi. Isu yang paling dominan terjadi di antara keempat isu tersebut yaitu mengenai pendukung atau tim sukses pasangan Presiden Jokowi-Ma'ruf. Informan mengatakan bahwa mereka siap dan setuju memilih pasangan Presiden Prabowo-Sandi ini. Mereka menganggap pasangan ini layak menjadi pemimpin karena dukungan yang banyak berasal dari kalangan ulama.

Berdasarkan penjabaran di atas, maka peneliti mengambil kesimpulan bahwa hasil analisis yang didapat adalah isu-isu politik yang paling dominan dibicarakan adalah kategori pemerintahan yang banyak membicarakan mengenai keburukankeburukan pada masa pemerintahan Jokowi selama 1 periode yang lalu. Ini dapat dibuktikan dengan hasil analisis yaitu banyaknya mahasiswa UKWP2SOSPOL yang membicarakan tentang banyaknya rakyat yang terzolimi di masa pemerintahannya dulu. Terutama berkaitan dengan tidak adanya perlindungan pemerintah terhadap rakyat biasa mengenai kekerasan yang dilakukan oleh aparat-aparat pemerintahan yang hanya karena membuat kericuhan disaat demo berlangsung, serta tidak diusutnya kematian ratusan anggota KPPS pada pemilu 2019.

Lebih lanjut, mahasiswa UNP UKWP2SOSPOL juga banyak membicarakan tentang janji-janji
Jokowi dimasa pemerintahannya dulu yang masih banyak tidak terealisasikan. Selanjutnya, dalam kategori pemerintah ini mahasiswa UNP UKWP2SOSPOL juga banyak membicarakan terkait dengan pembungkaman pendapat, yang mana masyarakat di takut-takuti oleh penahanan oleh pihak polisi apabila ketahuan menyebarkan berita hoax. Hal ini menyebabkan masyarakat menjadi takut untuk mengeluarkan kritikan serta pendapatnya apabila itu menyangkut mengenai hal-hal yang terkait dengan pemerintahan. Selanjutnya dari hasil analisis isu tersebut, dapat dilihat pula bahwa mayoritas dari pembicara di grup tersebut adalah pendukung Prabowo. Hanya terdapat empat orang yang pendukung Jokowi dan satu orangnya netral yang tidak memihak diantara kedua belah pihak Calon Presiden 2019 tersebut.

Terkait mengenai pembahasan kesebelas kategori isu politik dalam pemilihan presiden 2019 yang telah penulis jabarkan di atas maka dapat disimpulkan bahwa kategori pemerintahan adalah kategori yang mendominasi. Pembahasan lebih lanjut, disisi lain penulis juga melihat bahwa dari banyaknya pembicaraan mahasiswa UK-WP2SOSPOL terkait kategori pemerintahan ini, banyak yang komentarnya menjatuhkan pihak lawan. Hal ini dapat dilihat dari banyak mahasiswa UK-WP2SOSPOL yang dalam pembicaraan di grup WhatsAppnya lebih memihak kepada Prabowo tanpa melihat sisi positif yang ada pada Jokowi. Banyaknya dukungan terhadap Prabowo merepresentasikan besarnya dukungan terhadap Prabowo di Sumatera Barat. Hal itu diperkuat pula 
dari hasil rekapitulasi KPU di wilayah Sumatera Barat yang hasilnya Prabowo menang mutlak dari Jokowi. Prabowo mendapatkan 85,92\%, suara sedangkan Jokowi hanya meraup $14,08 \%$ suara.

Menjatuhkan pihak lawan dalam Pemilihan Presiden memang biasa terjadi Hal senada juga diungkapkan oleh Budiyono dalam Sari \& Samosir (2018) yang menyatakan bahwa komunikasi politik dengan menyampaikan pesan-pesan komunikasi yang buruk, menjatuhkan, dan menyerang pribadi merupakan persoalan yang biasa dalam konteks komunikasi politik melalui media sosial.

Penulis memperkuat temuan ini dengan hasil penelitian Juditha (2015) yang juga melakukan penelitian terkait isu politik dalam Pemilihan Presiden di media sosial Facebook. Hasil penelitiannya menyimpulkan bahwa kebijakan Prabowo bersifat global sementara Jokowi sektoral. Prabowo digambarkan sebagai pribadi yang percaya diri, tegas, kuat, amanah dan berpengalaman. Sementara Jokowi tergambar sebagai pribadi yang selalu mendengar, memperhatikan, mencintai, membela serta gemar blusukan. Prabowo ingin membangun demokrasi bangsa, sementara Jokowi berharap Indonesia sebagai negara berdaulat, berdikari, dan berkebudayaan. Dalam membangun pencitraannya, Prabowo sangat menonjolkan keinginan para pendukungnya, sedangkan Jokowi lebih menonjolkan program kerja. Dari pemaparan di atas dapat dilihat bahwa Jokowi dalam kepemerintahannya tidak semuanya buruk, ada kalanya dia pernah berbuat yang baik selama kepemerintahannya.

Namun

sayangnya banyak mahasiswa yang tidak mau untuk melihat sisi positifnya.

Selanjutnya, terkait dengan pembicaraan, masih di temukannya tutur kata mahasiswa yang kurang baik dalam menyampaikan aspirasinya. Dari hal ini dapat kita lihat bahwa tidak seharusnya sebagai masyarakat khususnya mahasiswa menyampaikan aspirasi seperti hal tersebut. Jika ingin menyampaikan suatu aspirasi, sampaikanlah dengan ketenangan dengan memikirkan katakata yang baik yang pantas untuk dikeluarkan. Bukan malah menjelekkan pasangan yang kita tidak suka dengan mengeluarkan kata-kata ejekan. Komunikasi dalam bermedia sosial harus dilakukan dengan tutur kata yang baik disertai dengan ketenangan. Bukan malah membuat kerusuhan dengan cara mengedepankan hasil pemikirannya sendiri tanpa mempertimbangkan hasil pemikiran orang lain.

Hal senada juga diungkapkan oleh Corry dalam Prasanti \& Indriani, (2017) yang mengatakan bahwa etika komunikasi tidak hanya berkaitan dengan tutur kata yang baik tetapi juga berangkat dari niat yang tulus yang diekspresikan dari ketenangan, kesabaran, dan empati kita dalam berkomunikasi. Dari hal ini, maka dapat penulis tarik kesimpulan bahwa dalam menyampaikan aspirasi atau hasil pemikiran kita di media sosial, haruslah dengan tutur kata yang baik, yang disertai dengan ketenangan, kesabaran, dan empati dalam berkomunikasi, agar komunikasi dalam bermedia sosial terjalin secara harmonis. 


\section{KESIMPULAN}

Berdasarkan analisis di kedua grup whatsapp, dapat dinyatakan bahwa kategori yang paling dominan dibicarakan oleh mahasiswa UNP UKWP2SOSPOL adalah kategori Pemerintahan. Hal tersebut dapat dilihat dari banyaknya mahasiswa yang membicarakan tentang banyaknya rakyat yang terzolimi di masa pemerintahan terdahulu Terutama berkaitan dengan tidak adanya perlindungan pemerintah terhadap rakyat biasa mengenai kekerasan yang dilakukan oleh aparataparat pemerintahan yang hanya karena membuat kericuhan disaat demo berlangsung. Serta tidak diusutnya kematian anggota KPPS sebanyak ratusan orang pada pemilu 2019. Lebih lanjut, mahasiswa UNP UKWP2SOSPOL juga banyak membicarakan tentang janji-janji Jokowi dimasa pemerintahannya dulu yang masih banyak tidak terealisasikan.

Selanjutnya dalam kategori pemerintah ini mahasiswa UNP UKWP2SOSPOL, juga banyak membicarakan terkait dengan pembungkaman pendapat, yang mana masyarakat ditakut-takuti oleh penahanan oleh pihak polisi apabila ketahuan menyebarkan berita hoax, hal ini menyebabkan masyarakat menjadi takut untuk mengeluarkan kritikan serta pendapatnya apabila itu menyangkut mengenai hal-hal yang terkait dengan pemerintahan.

\section{DAFTAR PUSTAKA}

Bungin, Burhan. 2006. Metodologi Penelitian Kualitatif. Jakarta: PT RajaGrafindo Persada

Eriyanto. 2011. Analisis Isi: Pengantar Metodologi untuk Penelitian
Ilmu Komunikasi dan IlmuIlmu Sosial Lainnya. Jakarta: Kencana Prenada Media Group JawaPos.com. (2018, 11 Agustus) Ternyata Ini Alasan Prabowo Tidak Gandeng Ulama Jadi Cawapresnya. Retrieved November 4, 2019, from https://www.jawapos.com/na sional/pemilihan/11/08/2018 / ternyata-ini-alasan-prabowotidak-gandeng-ulama-jadicawapresnya/

Juditha, C. 2015. Political Marketing dan Media Sosial. Studi Komunikasi dan Media, 19(2),225-240

Kompas.com. (2018, 9 Agustus). Pilih Ma'ruf Amin sebagai Cawapres, Jokowi Mengaku Saling Melengkapi.Retrieved November 4, 2019, from https:// nasional.kompas.com/ $\mathrm{read} / 2018 / 08 / 09 / 18503721 /$ pi lih-maruf-amin-sebagaicawapres-jokowi-mengakusaling-melengkapi

Prasanti, Ditha., \& Indriani, S.S. (2017). Etika Komunikasi dalam Media Sosial Bagi Ibu-Ibu PKK di Desa Mekarmukti Kab.Bandung Barat. Profetik Jurnal Komunikasi. 10(01), 21-34

Prathiwi, B. F. 2014. Persepsi Mahasiswa Tentang Calon Presiden Republik Indonesia 2014-2018.Skripsi:

UniversitasAtma Jaya Yogyakarta

Rahayu, A., \& Wijaya, T. (2017). Citra Calon Presiden Dan Calon Wakil Presiden Pada Pemilu 2014 (Studi Pada Mahasiswa FISIP Universitas Lampung Angkatan 2013). 2014, 298-311. 
Riyanto, B., dan Hastuti, N. H. 2017.

$\begin{array}{llr}\text { Literasi } & \text { Media Digital } \\ \text { Mahasiswa } & \text { Surakarta } & \text { dalam } \\ \text { Mensikapi Hoax di } & \text { Media } \\ \text { Sosial. Transformasi, I(33), 27-33 } \\ \text { G., \& Pitriani, R. } \\ \text { (2018). } \\ \text { Pengaruh Media Sosial } \\ \text { Instagram dan WhatsApp } \\ \text { Terhadap "Alone Together." } \\ \text { Budaya Pembentukan } \\ \text { JURNAL KOMUNIKASI, 10(2), } \\ \text { 103-114 }\end{array}$

Sugiyono. 2012. Metode Penelitian Kuantitatif Kualitatif dan R \& D. Bandung: ALFABETA

Sari, D., \& Samosir, F.T. (2018) Analisis Pola Respon Pengguna Media Sosial Menjelang Pemilihan Pasangan Calon Presiden dan Wakil Presiden 2019. Social and Political Challenges in Industrial 4.0

Suryanef. (2011). Persepsi Politik Mahasiswa Fis Universitas Negeri Padang. Demokrasi, X(2), 175-190

Suryani, R. (2017). Fungsi WhatsApp Grup Shalihah Cabang Bandar Lampung Sebagai Pengembangan Media Dakwah dalam Membentuk Akhlakul Karimah. Skripsi: Institut Agama Islam Negeri Raden Intan Lampung

Triastari, D. (2011). Persepsi Iklan Politik Pada Pemilih Pemula. Skripsi: Universitas Sebelas Maret Surakarta 